\author{
Dawid TALER $^{1}$ \\ Jan TALER ${ }^{2}$
}

\title{
DETERMINING HEAT TRANSFER CORRELATIONS FOR TRANSITION AND TURBULENT FLOW IN DUCTS
}

\begin{abstract}
The objective of the paper is to develop correlations for the Nusselt number $\mathrm{Nu}$ in terms of the friction factor $\xi(\mathrm{Re})$ and also Reynolds number Re and Prandtl number $\mathrm{Re}$, which is valid for transitional and fully developed turbulent flow. After solving the equations of conservation of momentum and the energy for turbulent flow in a circular tube subject to a uniform heat flux, the Nusselt number values were calculated for different values of Reynolds and Prandtl numbers. Then, the form of the correlation $\mathrm{Nu}=f(\mathrm{Re}, \mathrm{Pr})$ was selected which approximates the results obtained in the following ranges of Reynolds and Prandtl numbers: $2300 \leq$ $\operatorname{Re} \leq 1000000,0.1 \leq \operatorname{Pr} \leq 1000$. The form of the correlation was selected in such a way that for the Reynolds number equals to $\operatorname{Re}=2300$, i.e. at the point of transition from laminar to transitional flow the Nusselt number should change continuously. Unknown coefficients $x_{1}, \ldots, x_{\mathrm{n}}$ appearing in the heat transfer correlation expressing the Nusselt number as a function of the Reynolds number and Prandtl number were determined by the method of least squares. To determine the values of the coefficients at which the sum of the difference squares is a minimum, the Levenberg-Marquardt method is used
\end{abstract}

Keywords: tube flow, heat transfer, coefficient of friction, correlation for the Nusselt number, transition and turbulent flow

\section{Introduction}

There are only a few heat transfer correlations for internal flows in pipes and ducts which are valid in transition and turbulent regions [3, 5-8, 12]. Based on the suggestion of Hausen, Gnielinski [5] superseded the Reynolds number Re by the term $(\operatorname{Re}-1000)$ in the heat transfer correlation to include the transitional region. A drawback of the Gnielinski correlation was the lack of the Nusselt number continuity for the Reynolds number $\mathrm{Re}=2300$, i.e. at the point at which the flow evolves from the laminar to transition region. In the later works

\footnotetext{
${ }^{1}$ Autor do korespondencji/corresponding author: Dawid Taler, Cracow University of Technology, ul. Warszawska 24, 31-155 Kraków, tel. 1262830 26, e-mail: dtaler@pk.edu.pl.

2 Jan Taler, taler@mech.pk.edu.pl.
} 
[6-7] Gnielinski developed a new calculation method in the transitional flow based on the linear interpolation of the Nusselt number between $\mathrm{Re}=2300$ and $\operatorname{Re}=10000$ taking into account the finite length of the tube. In this way, continuity of the Nusselt number was assured in the range from $\operatorname{Re}=0$ to $\operatorname{Re}=1 \cdot 10^{7}$. It turned out, however, that in the range of Reynolds numbers from $\mathrm{Re}=4000$ to 20000 values of Nusselt numbers calculated using the interpolation formula proposed by Gnielinski are too large. For this reason, he changed his formula [8]. A linear interpolation between the Nusselt numbers at $\operatorname{Re}=2300$ and $\operatorname{Re}=$ 4000 , was proposed. The Nusselt number for $R e=2300$ is calculated from wellknown correlations for the laminar flow and for $\mathrm{Re}=4000$ the Nusselt number is determined using the modified Pietukhov correlation in which Re was replaced by (Re-1000). The disadvantage of all interpolation functions proposed by Gnielinski [6-8] is the need to specify the value of the Reynolds number for the end of the interval, in which the flow is transitional. Experimental studies show that in the range of Reynolds numbers: $2300<\mathrm{Re}<20000$ the Nusselt numbers are much smaller than those calculated from the correlations used for turbulent flow. Tam and Ghajar [12] proposed correlations for the turbulent, laminar and the transition regions for three different tube inlet configurations: reentrant, square-edged and bell-mouth. They found that transition from laminar to turbulent flow occurred at Reynolds number of 2900 to 3500 for the reentrant, 3100 to 3700 for the squared-edge, and at 5100 to 6100 for the bellmouth. They developed correlations to predict the critical Reynolds numbers for the different inlets and correlations to predict heat transfer in the transition region of flow. All correlations are approximate and may possess errors as much as 25 percent or larger. In this paper, a new correlation for the Nusselt number $\mathrm{Nu}$ in terms of the friction factor $\xi$, Reynolds number Re and Prandtl number $\mathrm{Re}$, which is valid for transitional and fully developed turbulent flow.

\section{Mathematical formulation of the problem}

At first, the Nusselt number as a function of Reynolds and Prandtl numbers will be calculated based on the solution of momentum and energy conservation equations for turbulent flow for $\operatorname{Re}>3000$. The turbulent velocity profile $\bar{w}_{x}$ is computed by solving the momentum conservation equation

$$
\frac{1}{r} \frac{d}{d r}\left[r \rho\left(v+\varepsilon_{\tau}\right) \frac{d \bar{w}_{x}}{d r}\right]=\frac{d p}{d x}
$$

where: $p$ - pressure, $r$ - radius, $x$ - cartesian coordinate, $\bar{w}_{x}$ - time averaged velocity, $v$ - kinematic viscosity, $\varepsilon_{\tau}$ - eddy diffusivity for momentum transfer (turbulent kinematic viscosity). 
Equation (1) is subject to the following boundary conditions

$$
\left.\frac{d \bar{w}_{x}}{d r}\right|_{r=0}=0,\left.\quad \bar{w}_{x}\right|_{r=r_{w}}=0 .
$$

Taking into account that the shear stress $\tau$ is defined as

$$
\tau=-\left(\mu+\rho \varepsilon_{\tau}\right) \frac{d \bar{w}_{x}}{d r}=-\rho\left(v+\varepsilon_{\tau}\right) \frac{d \bar{w}_{x}}{d r}=-\mu\left(1+\frac{\varepsilon_{\tau}}{v}\right) \frac{d \bar{w}_{x}}{d r}
$$

Eq. (1) can be rewritten in the form

$$
\frac{1}{r} \frac{d}{d r}(r \tau)=\frac{2 \tau_{w}}{r_{w}}
$$

Integration of Eq. (5) with the boundary condition

$$
\left.\tau\right|_{r=r_{w}}=\tau_{w}
$$

gives

$$
\tau=\tau_{w} \frac{r}{r_{w}}
$$

Substitution of Eq. (6) into Eq. (3) leads to

$$
\frac{d \bar{w}_{x}}{d r}=-\tau_{w} \frac{r}{r_{w}} \frac{1}{\mu\left(1+\frac{\varepsilon_{\tau}}{v}\right)}
$$

The solution to Eq. (7) should satisfy the boundary condition (2).The shear stress at the wall can be expressed as

$$
\tau_{w}=\xi \frac{\rho w_{m}^{2}}{8}
$$

Where the mean velocity $w_{m}$ is given by 


$$
w_{m}=\frac{2}{r_{w}^{2}} \int_{0}^{r_{w}} \bar{w}_{x} r d r
$$

The friction factor $\xi$ can be expressed in the form

$$
\xi=\frac{8}{\operatorname{Re}}\left[\int_{0}^{1}\left(\int_{R}^{1} \frac{R d R}{1+\frac{\varepsilon_{\tau}}{v}}\right) R d R\right]^{-1}
$$

To determine a velocity distribution $\bar{w}_{x}(r)$ and friction coefficient $\xi$ the eddy diffusivity for momentum transfer $\varepsilon_{\tau}$ will be calculated using Reichardt's [9] empirical equations, which so far are most commonly used because of the high accuracy of the measurement data

$$
\begin{array}{ll}
\frac{\varepsilon_{\tau}}{v}=\kappa\left[y^{+}-y_{n}^{+} \tanh \left(\frac{y^{+}}{y_{n}^{+}}\right)\right], \quad y^{+} \leq 50 \\
\frac{\varepsilon_{\tau}}{v}=\frac{\kappa}{4} y^{+}(1+R)\left(\frac{1}{2}+R^{2}\right), \quad y^{+}>50
\end{array}
$$

where: $R=r / r_{w}, \kappa=0.4$ and $y_{n}^{+}=11$.

The dimensionless distance from the tube wall is defined as

$$
y^{+}=\frac{y u_{\tau}}{v}=\frac{y \sqrt{\tau_{w} / \rho}}{v}=\frac{\left(r_{w}-r\right) \sqrt{\tau_{w} / \rho}}{v}
$$

where the symbol $u_{\tau}=\sqrt{\tau_{w} / \rho}$ denotes the so called friction velocity.

The velocity distribution can be obtained by solving Eq. (7) with the boundary conditions (2) considering empirical Equations (11) and (12).

The velocity distribution can be determined also from the formula proposed by Reichardt based on experimental data [9] 


$$
\begin{aligned}
u^{+} & =\frac{1}{\kappa} \ln \left[\left(1+0.4 y^{+}\right) \frac{1.5(1+R)}{1+2 R^{2}}\right]+ \\
& +C\left[1-\exp \left(-\frac{y^{+}}{11}\right)-\frac{y^{+}}{11} \exp \left(-\frac{y^{+}}{3}\right)\right], \quad 0 \leq R \leq 1
\end{aligned}
$$

where $C=7.8$ is the constant. The advantage of the equation (14) is that it gives the velocity profile $\bar{w}_{x}$ throughout the entire interval $0 \leq r \leq r_{w}$ without division of the tube cross-section into subdomains.

The energy conservation equation is

$$
\rho c_{p} \bar{w}_{x} \frac{\partial \bar{T}}{\partial x}=\frac{1}{r} \frac{\partial}{\partial r}(r \dot{q})
$$

where the heat flux $\dot{q}$ contains the molecular $\dot{q}_{m}$ and turbulent $\dot{q}_{t}$ component

$$
\dot{q}=\dot{q}_{m}+\dot{q}_{t}=\left(\lambda+\rho c_{p} \varepsilon_{q}\right) \frac{\partial \bar{T}}{\partial r}
$$

The symbols in Eqs. (15) and (16) denote: $\rho$ - density, $c_{p}$ - specific heat at constant pressure, $x$ - axial coordinate, $\varepsilon_{q}$ - eddy diffusivity for heat transfer.

Using the superposition principle, the fluid temperature can be expressed as the sum of the mass averaged temperature $\bar{T}_{1}(x)$ and radial temperature $\bar{T}_{2}(r)$

$$
\bar{T}(x, r)=\bar{T}_{1}(x)+\bar{T}_{2}(r)
$$

Taking into account that the heat flux at the tube wall $\dot{q}_{w}$ is constant, Eq. (15) can be transformed to the form

$$
\frac{1}{R} \frac{d}{d R}\left(R \frac{\dot{q}}{\dot{q}_{w}}\right)=2 \frac{\bar{w}_{x}}{w_{m}}
$$

Rearranging Eq. (16) gives

$$
\frac{d \bar{T}_{2}}{d R}=\frac{\dot{q} r_{w}}{\lambda\left(1+\frac{\operatorname{Pr}}{\operatorname{Pr}_{t}} \frac{\varepsilon_{\tau}}{v}\right)}
$$


where the Prandtl number (molecular) Pr and turbulent Prandtl number $\operatorname{Pr}_{t}$ are defined as

$$
\operatorname{Pr}=\frac{\nu}{a}=\frac{c_{p} \mu}{\lambda} \text { and } \operatorname{Pr}_{t}=\frac{\varepsilon_{\tau}}{\varepsilon_{q}}
$$

Equations (18)-(19) are subject to the boundary conditions

$$
\begin{aligned}
& \left.\lambda\left(1+\frac{\operatorname{Pr}}{\operatorname{Pr}_{t}} \frac{\varepsilon_{\tau}}{v}\right) \frac{1}{r_{w}} \frac{d \bar{T}_{2}}{d R}\right|_{R=1}=\dot{q}_{w} \\
& \left.\dot{q}\right|_{R=0}=0,\left.\frac{d \bar{T}_{2}}{d R}\right|_{R=0}=0
\end{aligned}
$$

The system of ordinary differential Equation (7) and (18)-(19) with the boundary conditions (2) and (20)-(22) was solved using the finite difference method. The heat transfer coefficient at the inner surface of the tube $\alpha$ was then calculated as

$$
\alpha=\frac{\dot{q}_{w}}{\left.\bar{T}_{2}\right|_{R=1}-\bar{T}_{2 m}}
$$

where $\bar{T}_{2 m}$ designates the mass average fluid temperature

$$
\bar{T}_{2 m}=\int_{0}^{1} \bar{w}_{x} \bar{T}_{2} R d R .
$$

Next, the Nusselt number values were calculated for different values of Reynolds and Prandtl numbers. The form of the function $\mathrm{Nu}=f(\mathrm{Re}, \mathrm{Pr})$ was selected which approximates the results obtained in the following Reynolds and Prandtl numbers: $2300 \leq \operatorname{Re} \leq 1000000,0.1 \leq \operatorname{Pr} \leq 1000$, where the dimensionless numbers are defined as

$$
\mathrm{Nu}=\frac{\alpha d_{w}}{\lambda}, \operatorname{Re}=\frac{w_{m} d_{w}}{v}, \operatorname{Pr}=\frac{c_{p} \mu}{\lambda} .
$$

Unknown coefficients $\mathbf{x}=\left(x_{1}, \ldots, x_{m}\right)^{T}$ appearing in the approximating function were determined using the least squares method 


$$
S(\mathbf{x})=\sum_{i=1}^{n_{\mathrm{Re}}} \sum_{j=1}^{n_{\mathrm{Pr}}}\left(\mathrm{Nu}_{i j}^{m}-\mathrm{Nu}_{i j}^{c}\right)^{2}=\min
$$

where: $\mathrm{Nu}_{i j}^{m}$ and $\mathrm{Nu}_{i j}^{c}$ - given and approximated values of the Nusselt number, respectively, $n_{\mathrm{Re}}=10$ and $n_{\mathrm{Pr}}=10$ - number of the Reynolds and Prandtl numbers which were taken into consideration in the sum (26).

It was assumed that for $3000 \leq$ Re the fluid flow in pipes with a smooth inner surface is turbulent. It results from the empirical formula proposed by Colebrook and White [11] and from the "Moody Chart" (Fig.1) which is based on the Colebrook-White formula. In addition, the condition $\mathrm{Nu}=4.364$ for $\mathrm{Re}=$ 2300 was imposed to ensure continuity of the Nusselt number on the boundary between laminar and transition flow.

Hence, the form of the approximating function was assumed as for the turbulent flow in smooth pipes

$$
\mathrm{Nu}=4.364+\frac{\frac{\xi}{8}(\operatorname{Re}-2300) \operatorname{Pr}^{x_{1}}}{x_{2}+x_{3} \sqrt{\frac{\xi}{8}}\left(\operatorname{Pr}^{2 / 3}-1\right)} \quad \begin{aligned}
& 2300 \leq \operatorname{Re} \leq 10^{6} \\
& 0.1 \leq \operatorname{Pr} \leq 1000
\end{aligned}
$$

where the friction factor $\xi$ is given by the Filonienko formula [5]

$$
\xi=(1.82 \log \operatorname{Re}-1.64)^{-2}
$$

The coefficients obtained by the least squares method are:

$$
x_{1}=1.008 \pm 0.0050, \quad x_{2}=1.08 \pm 0.0089, \quad x_{3}=12.39 \pm 0.0080 .
$$

The mean square error of the fit is $s_{t}=34.78$ and the coefficient of determination is equal to $r^{2}=0.9999$. The correlation (27) was generalized to account for the finite length of the channel and temperature dependent thermal properties of the fluid

$$
\begin{aligned}
& \mathrm{Nu}=\mathrm{Nu}_{m, q}(\mathrm{Re}=2300)+\frac{\frac{\xi}{8}(\mathrm{Re}-2300) \operatorname{Pr}^{1.008}}{1.08+12.39 \sqrt{\frac{\xi}{8}}\left(\operatorname{Pr}^{2 / 3}-1\right)} \times \\
& \times\left[1+\left(\frac{d_{w}}{L}\right)^{2 / 3}\right]\left(\frac{\operatorname{Pr}}{\operatorname{Pr}_{w}}\right)^{0.11}, 2300 \leq \operatorname{Re} \leq 10^{6}, 0.1 \leq \operatorname{Pr} \leq 1000, \frac{d_{w}}{L} \leq 1
\end{aligned}
$$


where the symbol $\mathrm{Nu}_{m, q}$ denotes the Nusselt number for the laminar flow, which can be calculated, for example, using the formulas given in [VDI]

$$
\mathrm{Nu}_{m, q}=\left[\mathrm{Nu}_{m, q, 1}^{3}+0.6^{3}+\left(\mathrm{Nu}_{m, q, 2}-0.6\right)^{3}+\mathrm{Nu}_{m, q, 3}^{3}\right]^{1 / 3}
$$

with

$$
\begin{aligned}
& \mathrm{Nu}_{m, q, 1}=\frac{48}{11}=4.364 \\
& \mathrm{Nu}_{m, q, 2}=1.953\left(\operatorname{Re} \operatorname{Pr} \frac{d_{w}}{L}\right)^{1 / 3} \\
& \mathrm{Nu}_{m, q, 3}=0.924 \operatorname{Pr}^{1 / 3}\left(\operatorname{Re} \frac{d_{w}}{L}\right)^{1 / 2}
\end{aligned}
$$

The symbols $d_{w}$ and $L_{w}$ in Equations (29)-(30) denote inner or hydraulic diameter and the length of the channel, respectively.

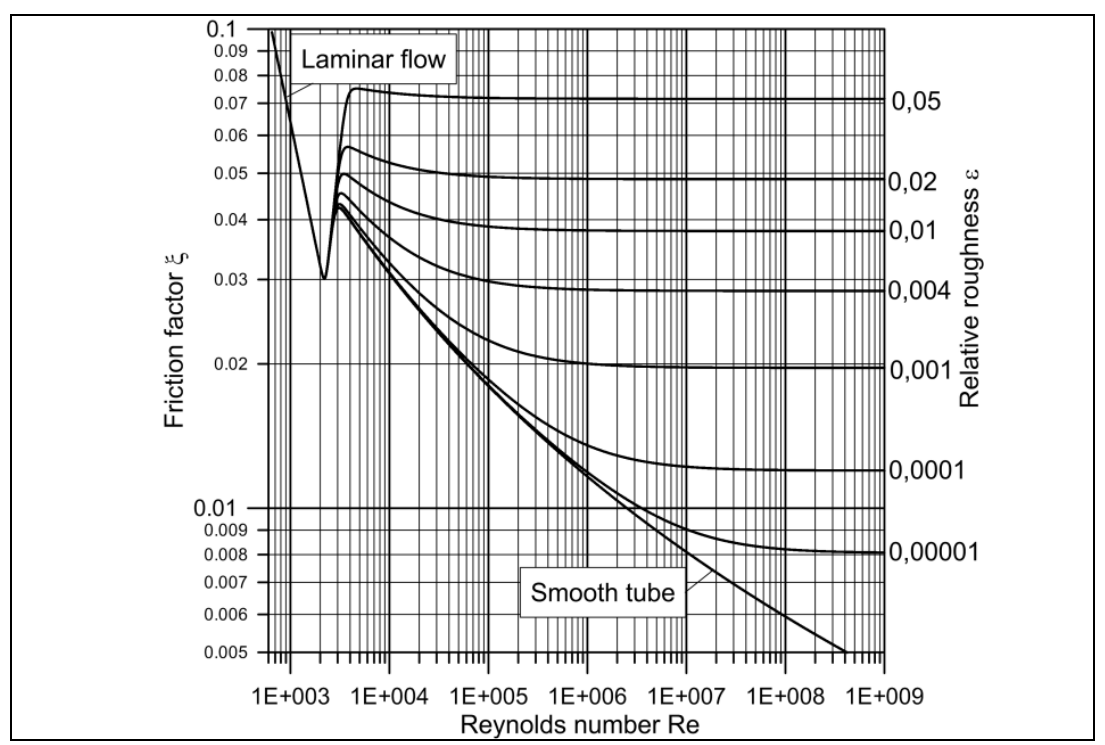

Fig. 1. Friction factor versus Reynolds number and relative roughness for commercial pipes 


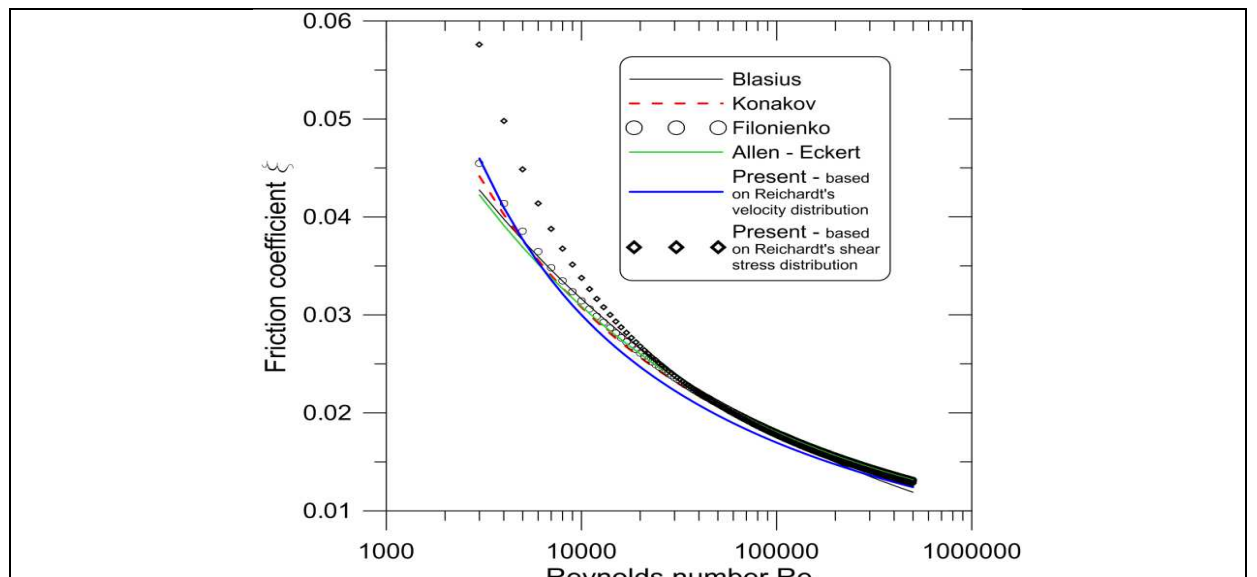

Fig. 2. Comparison of calculated friction factors for smooth pipes with the results obtained using the formulas proposed by Blasius, Filonienko, Konakov [5-8], and Allen and Eckert [1]

\section{Comparison with experimental data}

The various explicit formulas for turbulent friction factor, when the tube surface is smooth, are compared in Fig. 2 with the results obtained using Eq. (10) in conjunction with the formulas (11) and (12). Furthermore, the friction factor was calculated from the formula $\xi=8 /\left(u_{m}^{+}\right)^{2}$ where the symbol $u_{m}^{+}$denotes the mean velocity $u_{m}^{+}=2 \int_{0}^{1} u^{+} R d R$. The velocity distribution $u^{+}$was determined from the Reichardt experimental formula (14).

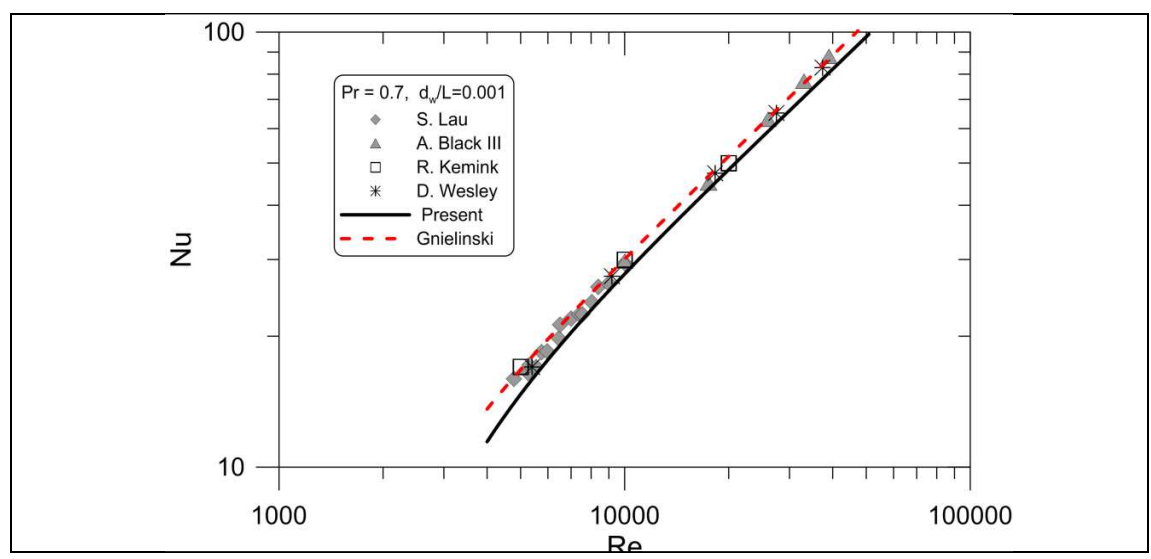

Fig. 3. Comparison of the results obtained using formula (29) with experimental data by Lau, Black, Kemink, and Wesley [8] and the method of calculation proposed by Gnielinski [8] 


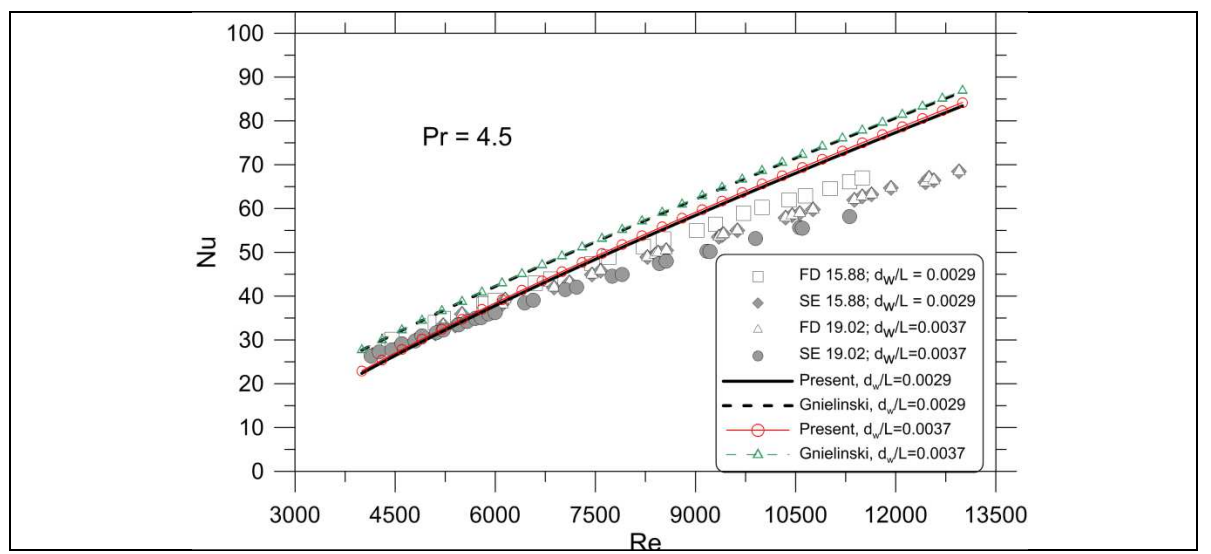

Fig. 4. Comparison of the results obtained using formula (29) with experimental data by Olivier and Meyer [10] and the method of calculation proposed by Gnielinski [8]

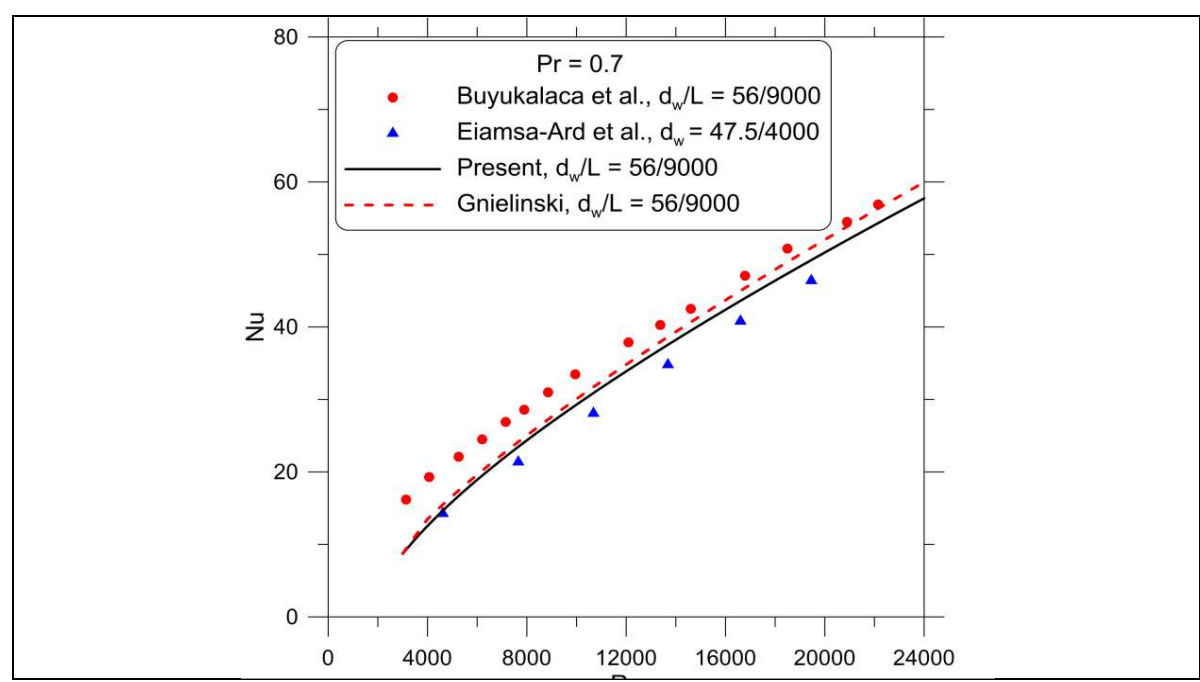

Fig. 5. Comparison of the results obtained using formula (29) with experimental data by Buyukalaca et al. [2] and Eiamsa-Ard et al. [4] and the method of calculation proposed by Gnielinski [8]

An inspection of the results shown in Fig. 2 indicates that for small Reynolds numbers the use of the experimental velocity distribution (14) given by Reichardt to calculate the friction factor $\xi$ for small Reynolds numbers gives very satisfactory results. The formula (29) proposed in this paper is compared in Figures 3-5 with experimental data available in literature.

The comparisons presented in Figures 3-5 show that Eq. (29) gives results which are in good agreement with the experimental data. From the analysis of 


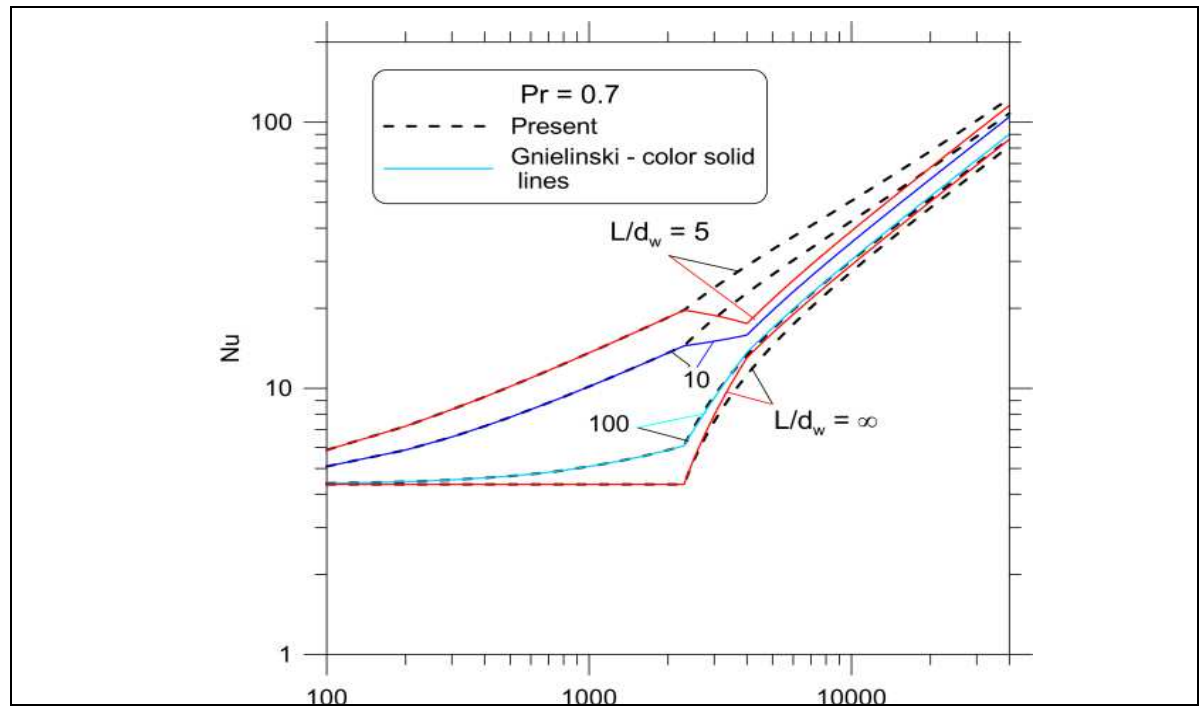

Fig. 6. Comparison of the results obtained using formula (29) and the method of calculation proposed by Gnielinski [8]

the results presented in Fig.6 it can be seen that the new linear interpolation between the equations for laminar and turbulent flow in the transition region developed recently by Gnielinski exhibits unusual behavior for short pipes.

\section{Conclusion}

A new equation for the Nusselt number for transition and turbulent flow in channels has been proposed. The heat transfer equation developed in the paper approximates very well experimental data.

\section{References}

[1] Allen R. W., Eckert E. R. G.: Friction and heat-transfer measurements to turbulent pipe flow of water $(\operatorname{Pr}=7$ and 8$)$ at uniform wall heat flux, Transactions of the ASME, J. Heat Transfer, 86 (1964) 301-310.

[2] Buyukalaca O., Ozceyhan V., Gunes S.: Experimental investigation of thermal performance in a tube with detached circular ring turbulators, Heat Transfer Eng., 33 (2012) 682-692.

[3] Churchill, S. W.: Comprehensive correlating equations for heat, mass and momentum transfer in fully developed flow in smooth tubes, Ind. Eng. Chem. Fundam, 16 (1977) 109-116.

[4] Eiamsa-Ard S., Kongkaitpaiboon V., Promvonge P.: Thermal performance assessment of turbulent tube flow through wire coil turbulators, Heat Transfer Eng., 32, (2011) 957-967. 
[5] Gnielinski, V.: Neue Gleichungen für den Wärme- und den Stoffübergang in turbulent durchströmten Rohren und Kanälen, Forschung im Ingenieurwesen (Engineering Research), 41 (1975) 8-16.

[6] Gnielinski, V.: Ein neues Berechnungsverfahren für die Wärmeübertragung im Übergangsbereich zwischen laminarer und turbulenter Rohrströmung, Forschung im Ingenieurwesen (Engineering Research), 61 (1995) 240-248.

[7] Gnielinski V.: Durchströmte Rohre, Abschnitt G1, VDI-Wärmeatlas 11., bearbeitete und erweiterte Auflage, Springer-Vieweg, Berlin-Heidelberg 2013, pp. 785-791.

[8] Gnielinski, V.: On heat transfer in tubes, Int. J. Heat Mass Transfer, 63 (2013) 134140.

[9] Reichardt H.: Vollständige Darstellung der turbulenten Geschwindigkeitsverteilung in glatten Leitungen, Z.Angewandte Math. Mechanik, 31 (1951) 208-219.

[10] Olivier J. A., Meyer J. P.: Single-phase heat transfer and pressure drop of the cooling water inside smooth tubes for transitional flow with different inlet geometries, HVAC\&R Research, 16 (2010) 471-496.

[11] Rennels D. C., Hudson H.M.: Pipe flow. A practical and comprehensive guide, AIChE, Wiley, Hoboken 2012.

[12] Tam, L. M. \& Ghajar A. J.: Transitional heat transfer in plain horizontal tubes, Heat Transfer Eng., 27 (2006) 23-38.

\section{WYZNACZANIE KORELACJI NA LICZE NUSSELTA DLA PRZEPLYWU PRZEJŚCIOWEGO I TURBULENTNEGO}

\section{Streszczenie}

Celem pracy było wyznaczenie korelacji na liczbę Nusselta Nu w funkcji współczynnika $\operatorname{tarcia} \xi(\operatorname{Re})$ oraz liczby Reynoldsa Re i Prandtla Pr, która obejmuje zakres przejściowy i turbulentny. Po rozwiązaniu równań zachowania pędu i energii dla przepływu w rurze na powierzchni, której zadana jest stała gęstość strumienia ciepła wyznaczono liczbę Nusselta w funkcji liczby Reynoldsa i Prandtla. Następnie wybrano funkcję przybliżającą $\mathrm{Nu}=\mathrm{f}(\mathrm{Re}, \mathrm{Pr})$, w której nieznane współczynniki wyznaczono metodą najmniejszych kwadratów. Zaproponowana korelacja na liczbę Nusselta ważna jest w przedziałach: $2300 \leq \operatorname{Re} \leq 1000000,0.1 \leq \operatorname{Pr} \leq 1000$. Postać korelacji została wybrana w taki sposób, że dla liczby Reynoldsa $R e=2300$, tj. w miejscu przejścia od przepływu laminarnego do przejściowego liczba Nusselta powinna zmieniać się w sposób ciągły. Nieznane współczynniki $\mathrm{x}_{1}, \ldots, \mathrm{x}_{\mathrm{n}}$ występujące $\mathrm{w}$ korelacji przejmowania ciepła $\mathrm{i}$ wyrażające liczbę Nusselta w funkcji liczby Reynoldsa i liczby Prandtla określono metodą najmniejszych kwadratów. W celu określenia wartości współczynników przy których suma kwadratów różnicy jest minimalna, zastosowano metodę Levenberga-Marquardta.

Słowa kluczowe: przepływ w rurze, współczynnik tarcia, korelacja na liczbę Nusselta, przepływ w zakresie przejściowym i turbulentnym

DOI: $10.7862 / \mathrm{rm} .2014 .12$

Otrzymano/received: 15.05 .2014

Zaakceptowano/accepted: 27.05.2014 